\title{
Virginia Woolf and the Exploration of the Third Gender
}

\author{
Iraj Montashery \\ Lahijan Branch, Islamic Azad University, Lahijan, Iran
}

Received: 24-02- 2013

doi:10.7575/aiac.ijclts.v.1n.1p.1
Accepted: 05-04- 2013

Published: 30-04- 2013

\begin{abstract}
One of Woolf's chief considerations in her fiction of 1920s was to heal the split between the mother and language or the symbolic order on the one hand and to revise the previous Western binary thinking regarding the construction of gender identity on the other. I argue that Woolf refused the 'either/or' logic of dichotomous models by offering a space which includes the advantages of both the symbolic and the semiotic, which in turn introduces the new logic of 'both/and'. This space fuses masculine and feminine identities. It is speech and pleasure, textuality and sexuality, sameness and difference. It is a space for both men and women. This article attempts to relate subjectivity to desire. Therefore, I shall uncover a new subject position and space between Lacanian symbolic and Kristevan semiotic, in order to construct inbetween (third) gender identities based on characters' desires for a lost maternal space.
\end{abstract}

Keywords: Third gender, Desire, Symbolic, Semiotic, Maternal space, Identity

\section{Introduction}

People find it indispensable to define and develop a sense of who they are in the course of their lives. Identity is a set of persistent personal, behavioural and mental characteristics and qualities by which an individual is recognisable or distinguishable. Identity construction is interlocked, intertwined and theorised in terms of its relationship to gender, language, power, culture, race, politics, etc. In a broad classification which tends to go beyond individual identities, one is able to realise cultural, ethnic, religious, racial and national identities, which are either tied into the identity of a group or culture, or of an individual, insofar as he/she is related to a particular culture or ethnicity. Since these identity categorisations are concerned with larger groups, I will focus on individual gender identity, which is the landmark of psychoanalysis. Nick Mansfield approaches the issue through dividing it into two main categories: the psychoanalytic/subjective and the Foucauldian/anti-subjective. He argues that:

In sum, psychoanalysis is the key school of thought which attempts to explain the truth of the subject, how our interior life is structured, how it has been formed, and how it can explain both uniquely individual traits (for example, nervous habits and sexual tastes) and vastly public ones (for example, the politics of gender and culture). Its authority rests on the assumption, found nearly everywhere in Western thought in the modern era, that its object of analysis is quantifiable and knowable - in short, a real thing, with a fixed structure, operating in knowable and predictable patterns (Mansfield, 2000: 9).

Within this broad category lie the works of Sigmund Freud, Jacques Lacan, Julia Kristeva and Luce Irigaray, among others. The second approach, which takes its name from Foucault, is anti-subjective; within it lie a number of theories, including those of Foucault himself, and Friedrich Nietzsche. Mansfield notes that in this approach:

[S]ubjectivity is not a really existing thing, but has been invented by dominant systems of social organisation in order to control and manage us. We are educated and harassed till we believe that the proper organization of the world depends on the division of the human population into fixed categories - the sick separate from the well, the sane from the insane, the honest from the criminal-each exposed to different types of management, in the hands of doctors, social workers, police, teachers, courts and institutions (from schools to prisons, factories to hospitals, asylums to the military), all regulated according to rationalised principles of truth and knowledge. In this way, 'subjectivity' is not the free and spontaneous expression of our interior truth. It is the way we are led to think about ourselves, so we will police and present ourselves in the correct way, as not insane, criminal, undisciplined, unkempt, perverse or unpredictable. (Mansfield, 2000: 10)

In light of Mansfield's classification, I will treat the subject as a subjective category which is 'knowable' and its truth is explainable. To me, the subject is not merely an illusion constructed by the dominant power system in society, but is rather a real thing - the truth of which can be discovered through psychoanalytic approaches. It needs to be noted that both of the schools of thought described above share a common concern regarding the subject: that the subject is a construct. It is constructed within the world, and is not a preformed essence, as the Enlightenment thinker, Rene Descartes (1596-1650) believed:

[T]he idea that we are possessed of a free and autonomous individuality that is unique to us, and that develops as part of our spontaneous encounter with the world. Martin Heidegger's contribution to the present-day crisis of subjectivity, as it has been called, was to propose that this model of the subject was a superficial illusion perpetuated on us by Descartes and the philosophers he influenced. (Mansfield, 2000: 11) 
This assumption then, allows me to question the validity of existing notions of gender and identity, and paves the way for new constructions which accommodate and celebrate the fluid and volatile nature of gender and identity. In this paper, I will follow a poststructuralist lead which postulates that identities, far from being given in advance for individuals to step into, emerge over time through discursive and other social practices.

Mansfield notes that the "key influences on subjectivity, according to psychoanalysis, are gender and sexuality that produce a separation between conscious and unconscious minds, governed by imagery, language and desire" (Mansfield, 2000; 184). Clare Hanson, meanwhile, notes that "psychoanalysis offered two things for female modernist writers: a new subject area, or rather, new ways of defining/interpreting female subjectivity, and new techniques such as free association, the use of dreams and symptomatic writing" (Hanson, 1994: 2). As such, I will locate my study within Lacanian and Kristevan psychoanalysis, feminism and gender studies.

But it is first necessary to make a distinction between sex and gender: while sex is widely conceived to be a biological and anatomical determinant with which we are born (a person's identification as male or female), gender could be largely, if not entirely, independent of anatomy, and is a social construct. This social construct is the outcome of the dominant ideology in a given historical period, but which generally remains largely patriarchal in its biases towards women. Thus, gender can either be masculine or feminine with regard to personality traits or behaviour. In this study, I will explore the possibility of a space in between these two deep seated dichotomies: a 'third gender', or an 'in-between identity'.

\section{Sexual and Gender Identity}

In psychoanalytic studies, identity is divided into two subcategories: sexual and gender identity. Sexual identity follows the biologically determined traits of maleness and femaleness, and its trajectory is normally predetermined in a given patriarchal society. Sexual identity explains how persons identify their own sexuality, which may or may not relate to their actual sexual orientation. Therefore, in general, sexual identity describes the sex with which a person identifies, or is identified. On the other hand, gender identity refers to a person's awareness of his/her masculine/feminine identity, which is a set of culturally constructed and assigned roles for each category. The sense of masculinity and femininity is not biologically determined, and they do not necessarily accord to one's sexuality. The dominant view in patriarchal societies, however, endorses it as such, and condemns all other forms of practices of sexuality other than heterosexuality as perversions.

More often than not, gender identity stems out of the biological attributes of maleness and femaleness. Although there is a wide range of correspondence between gender identity and biological sex due to cultural and social expectations, it should not be taken as a natural fact. Sometimes, the gender roles assigned for a particular sexuality are not able to render, represent or contain the real identity of the person. It is here that the inconsistency between sexual and gender identity challenges the hegemony of patriarchy in sketching and determining the trajectory of subjects' desires and their gender identities respectively. In this study, I take such inconsistencies as a starting point to challenge and transform the existing definitions and configurations concerning identity in general, and gender identity in particular.

To me, subjectivity is experience, and is therefore open to contradiction and inconsistency; any attempt, therefore, at uttering a final word on the human subject is inevitably doomed to failure. Virginia Woolf's fiction written during the 1920 s consciously poses significant questions regarding these inconsistencies, chief of which is the inconsistency between sexual and gender identity. In her novels of this period, characters' gender identities do not easily pertain to the prescribed and available identity categories. Woolf throws the validity of some prescribed gender identities into question; she does not simply accept that there are unambiguously male and female human beings, who are expected to behave naturally and appropriately as men and women. In other words, Woolf contends that it is a myth that males should adopt gender roles appropriate to masculinity, and females in turn should adopt gender roles appropriate to femininity. Therefore, I shall uncover a new subject position and space between masculine and feminine gender and identity, which I shall label in-between identity or third gender. This third gender is quite distinct from the concepts of androgyny and bisexuality, in that androgyny refers to the quality of being mentally male and female simultaneously which according to Woolf is a prerequisite for genuine artistic creation: "Woolf had previously argued that an androgynous ontology is vital to creativity. Writing to her sister Vanessa Bell ... Woolf claimed that all great artists ... were "hermaphrodite, androgynous" (Hargreaves, 2005: 74); and bisexuality indicates the existence of a desire for both sexes in an individual.

The concept of androgyny which Woolf draws from Coleridge is put forward in its new reformulation in her $A$ Room of One's Own (1929). Here she contemplates as to whether there might be "two sexes in the mind corresponding to the two sexes in the body," which could

be united in order to get complete satisfaction and happiness...It is when this fusion takes place that the mind is fully fertilized and uses all its faculties. Perhaps a mind that is purely masculine cannot create, any more than a mind that is purely feminine. (Woolf, 1929: 102)

Tracy Hargreaves argues that "Woolf located androgyny first as a form of balanced coexistence, redolent of Jung's anima and animus: 'in each of us two powers preside, one male, one female; and in the man's brain the man predominates over the woman, and in the woman's brain the woman predominates over the man"' (Hargreaves, 2005: 69)

Brenda Sue Helt explores the concept of bisexuality in Woolf, especially with regards to Orlando: A Biography (1928), and notes that 
Woolf's literary portrayals of bisexual desire challenged the looming threat of a large-scale cultural consecration of the heterosexual/homosexual identity dyad...Woolf's work most often frames same-sex desire and sexuality as normative, as ordinary, and as harmonious with women's desire. (Helt, 2008: 250-1)

Although one can trace the existence of bisexual desire in most of Woolf's 1920s novels, the characters nevertheless evade an identity construction based solely on bisexual desires. Instead, they attempt to escape binary polarities and dichotomies based on their desire for the maternal space. To me, one of Woolf's chief considerations in her fiction is to heal the split between the mother, and language or the symbolic order. Woolf's 1920s works are predominantly based on woman-centred relationships, which aim at escaping the appropriative structures of patriarchy. Such relationships between women foreground the necessity of a positive identification with the maternal, and not necessarily a lesbian relationship. In To the Lighthouse (1927), for instance, Lily's relationship with Mrs Ramsay tends to be physical at times, but it is simultaneously the source of her newly developed feminine language. Such woman-centred relations allow Woolf to develop a new intellectuality which promotes woman-identified values and ways of knowing, which retrieves its power and initiatives from the maternal space. In Mrs Dalloway (1925) and To the Lighthouse, such woman-to-woman relations are both intellectual and physical.

Woolf and some of her contemporaries like Joyce and Richardson were struggling to portray modern subject and consciousness which tended to be more fluid and unstable in comparison with the notion of the self as stable and rational in pre-modern periods. Consequently, subjective consciousness turned to be the cornerstone of the modernist novel and influenced its main themes and dominant techniques (Parsons, 2007: 56).

To render this view of subject, the traditional conventions of earlier prose fiction, like narrative continuity and coherence, was also quite inadequate; for this reason, Woolf devised a new form and style to subvert these traditional conventions of writing and narrative by use of innovative modes or techniques of narration-like stream-of consciousness-which could render the fragmentary nature of this newborn subject. As an outstanding literary innovator, she employed these novel techniques to depict inner experience and capture the essence of the impressionable self. Her form and subject matter were inextricably intertwined and bound to each other.

\section{Woolf's Rejection of Binary Thinking}

Numerous studies have explored the myriad ways in which identity is constructed in Woolf's fiction, which in turn mirror the complexity of such construction in her works. Psychoanalytically speaking, sex and sexuality are significant indicators of the construction of gender identity - as noted above, one of the major and dominant beliefs in patriarchal societies - but Woolf's radical thinking in relation to the construction of gender identity, which she directly connects to desire and femininity, decisively breaks away from patriarchal values and notions regarding identity construction. In this study, I argue that Woolf revises the previous Western binary thinking regarding the construction of gender identity.

In her Revolution in Poetic Language (1984), Kristeva distinguishes between two aspects of linguistic modalities: the semiotic and the symbolic. The symbolic corresponds with Lacan's symbolic order, and constructs subjects through language; while the semiotic is the physical basis of language - its sounds, tones, and rhythms, which originate in the body. The semiotic, being physical, is therefore "a psychic modality logically and chronologically prior to the sign: without this bodily basis there could be no symbolic, no language or culture" (Jantzen, 1999: 195). Kristeva, in describing the formation of the subject, theorises that the subject is always divided and split between the symbolic and the semiotic, and is never a unified whole, but rather a "subject-in-process" (McAfee, 2004: 38); this means that, "as speaking beings, we are always works in progress. Our subjectivity is never constituted once and for all" (McAfee, 2004: 43). In her view, if women are subjected to the symbolic order, they are forced to play stereotyped and fixed traditional gender roles, and therefore remain marginalised and take already prescribed positions.

Rena Otsuka, in her analysis of Woolf's Mrs Dalloway and To the Lighthouse concludes that the reader is never able to pin down definitively Clarissa's and Lily's respective identities, because their identities are situated between the symbolic, which represents oppressive patriarchy, and the semiotic, which represents maternal power: in Mrs Dalloway, Clarissa obtains multiple identities through the use of layered narrative strategies, such as stream-of-consciousness, and the split between death (the semiotic) and life (the symbolic). In To the Lighthouse, Woolf seeks to preserve the fluid nature of the self, which continually moves between the symbolic and the semiotic, and away from the oppressive dominance of symbolic patriarchy (Otsuka, 2008: 30). Similarly, Micki M. Nyman argues that Woolf's fiction uncovers the symbolic or the phallocentric register and its heterosexual base, which limits women's freedom and requires a psychic space between materiality and signification (Nyman, 2005: 122). Michele Laura Hilton, meanwhile, argues that women characters in To the Lighthouse demonstrate the possibility of a subject position between the Kristevan semiotic and the Lacanian symbolic (Hilton, 1996: 96).

In this paper, I continue to locate and secure a space between the Lacanian symbolic and Kristevan semiotic in Woolf's works, in order to construct in-between gender identities based on her characters' desires for a lost maternal space. The in-between gender identity can be studied through Woolf's characters like Bernard and Rhoda in The Waves, Clarissa in Mrs Dalloway, and Lily in To the Lighthouse, who resist the limitations of the symbolic order, and therefore bring the already existing but socially repressed desire for the maternal space to the forefront of consciousness under the power of the maternity.

In Mrs Dalloway, different forms of non-linguistic signification together with structural innovations and new methods of narrations, like stream-of-consciousness, introduce a new understanding and configuration of characters' identity; in this respect, desire functions as a subtext to deconstruct and disturb social and cultural norms regarding heterosexuality, gender identity and the sequential nature of language as well. Woolf employs a different system of signification in this novel, which is the inscription of semiotic elements through a desire for the repressed maternal space, so as to undermine and challenge traditional fictional forms, norms and structures of oppression (i.e., heterosexism), and to question the sole hegemony of masculinity in the construction of gender identity. This particular system of signification 
speaks the unspeakable, as it were, in the Western literary and philosophical tradition, especially in terms of the complex configurations of gender, desire and sexuality which structure subjectivity.

Woolf in Mrs Dalloway employs a plural system of signification to inscribe the semiotic, and to depict the reality of characters and things because symbolic language is not able to render, and even distorts reality. This plural signification can assume different forms, and includes wordless moments, ecstasy, physical touch, scent, sight, colours, music and silence. When Clarissa and Sally kiss each other, for instance, their lips speak together and produce a unique and exquisite language in which signifier and signified overlap. Such a language, which attempts not to use words as its signifiers, stems from characters' original desires for the maternal space where there was no language, no lack or identity whatsoever. Therefore, even Clarissa's desire for Sally is not the end of the quest; there is still the ceaseless search and desire for the maternal space which is never fulfilled. Woolf's subversive use of epiphanic moments to portray female homoeroticism and desire could be considered an attempt to construct maternal space within the constraints of the symbolic order. When two female lips speak together in an exquisite way within the restrictive domain of the symbolic, this introduces rupture into the patriarchal language.

In To the Lighthouse, Lily Briscoe is positioned between the maternal figure Mrs Ramsay, and the paternal figure $\mathrm{Mr}$ Ramsay; she painfully struggles to find a purely feminine form of expression to escape patriarchal ideology and language, which only accommodate and value masculine identity. To this end, Lily awakens her desire for the maternal space to resist patriarchal values; in doing so, she inscribes those desires through the development of a feminine language in her painting. This feminine language disrupts and subverts the culturally constructed hegemony of masculine identity, the latter of which relegates feminine identity to a marginal and subordinate position. Consequently, through her feminine language, Lily is ultimately able to construct a gendered identity for herself, which defies absolute identification with either the paternal or the maternal. I argue that Lily follows exactly Kristeva's prescription regarding the formation of identity: she neither submits herself to the devastating structure of the symbolic order, nor the limiting horizon of complete identification with the mother; in this respect, Lily's persistent preoccupation with striking a balance in her painting makes full sense. She notes that "For whatever reason she could not achieve that razor edge of balance between two opposite forces; Mr Ramsay and the picture" (To the Lighthouse, 143). Lily has already come to terms with the fact that she is not going to follow the path Mrs Ramsay prescribed for women. This in-between state offers Lily a vantage point of standing apart from the sole symbolic or the semiotic order, and she is able to construct a fluid identity which is the sum total of both the symbolic and semiotic orders, instead of succumbing to patriarchal either/or binary thinking. Lily's identity could be located within the logic of both/and, which Woolf encourages in this novel.

In The Waves, as Bernard's narrative progresses, he grows increasingly dissatisfied and frustrated by its sequential order and the binary thinking which governs it. By the time his storytelling nears the end, Bernard develops a type of feminine language in which symbolic language is not completely erased. Bernard is doubtful of his gender now due to the deconstruction of symbolic language and its subsequent binary thinking, and this opens up a space for a more fluid definition of gender and identity for Bernard - which was already accessible to Rhoda. Therefore, the previous rigidly defined differences of gender are not seen as a site for oppositions, in which the masculine will always be dominant, and the feminine subordinate. In this new configuration, the gender binary is deconstructed as Bernard notes that: "[t]his difference we make so much of, this identity we so feverishly cherish, was overcome" (The Waves 163). "Difference" in this new configuration is seen as a positive exchange area between masculinity and femininity.

Desire is always implicated through language, and the growing desire for the maternal space in characters like Clarissa and Septimus is indicated through an especial system of signification, which is quite different from symbolic language. The desire of returning to the maternal space and subsequently moving away from rigid phallocentric language creates a specific kind of language for characters, called écriture féminine. The literary theory of écriture féminine, or feminine/female writing, derives from the French feminist Hélène Cixous' revisions of Lacanian theory. According to Lacan, an infant moves during its earliest psychosocial development from an imaginary order-which is the mothercentred, non-subjugated, pre-symbolic, pre-Oedipal space of bodily drives and rhythms (linked with the unconscious) to a symbolic order of separation between self and (m)other, of law and patriarchal social codes, and of loss and associated desire (linked with consciousness). Écriture féminine is a radical, disruptive mode of feminine writing that is opposed to patriarchal discourse, with its rigid grammar, boundaries, and categories. As Keith Green and Jill LeBihan note,

the force of patriarchy is always inscribed upon women, and upon men also, by the prevailing symbolic systems; it is a fundamental belief of écriture féminine that the only way to transform relations between the sexes is to transform the ways in which we represent these relations. (Green and LeBihan, 1996: 243)

For this very reason écriture féminine asks for an alternative form of language to allow this transformation to happen. The use of écriture féminine can be observed when characters move away from the phallogocentric language of the symbolic towards the fluid language of the semiotic in their quest of constructing in-between identities. Although previous studies have shown the role of the semiotic, and its effects on characters' use of language in Woolf's works, they have not acknowledged the significant role of the semiotic in the construction of identity type. In this paper, I mainly argue that a new type of identity, called an in-between identity, and which is the sum total of the Lacanian symbolic and Kristevan semiotic, is recognisable in Woolf's works. Previous studies consent that while characters enter the patriarchal world of the symbolic order, they leave and repress their desire of the maternal space at the cost of constructing their identities, which in turn is defined after patriarchal values. But my study argues that Woolf's characters resist these prescribed identity types - construction of the symbolic order only, and hence under the presence of maternal power - which then awakens their repressed desires for the maternal space, and causes them to gradually move away from the symbolic order towards the maternal space of the semiotic. 
Although characters strive for and long to recapture the maternal space- to retain the original wholeness and unity once they shared with their mothers - the unattainability and impossibility of returning to that space creates a new space, which is the intersection of the symbolic and the semiotic. Occupying this space, characters also employ a language which is the sum total of both symbolic and semiotic elements. The characters' practice of desire also carries both elements of the symbolic, which are the predefined and prescribed fixed gender roles, and the desire for maternal space; the resultant in-between identity carries both elements at the same time. The desire to recapture the maternal space can be observed through characters' écriture féminine, suicide, death or in some cases, their lesbian desires.

Helt argues that thinking through desire, and not through sex or sexuality, is central to Woolf's concept of the artist, and concludes that "[d]esire is so multiple, so varied, that the search to satisfy it must not be bounded by constructed limitations such as gender and sexuality" (Helt, 2008: 284). Therefore, in Woolf's three aforementioned novels, it is not easy to identify and assign predetermined and prescribed gender roles for Woolf's characters within the hegemonic and androcentric heterosexual reality, since the character's desires are not limited to the demands of heteronormativity. Within patriarchy, even anatomical differences are mapped to expectations about sexual desire, specifically to society's compulsory heterosexuality, which argues that there are two sexes and that desire runs from one sex to the other. But in the three Woolf novels in question, characters challenge this inevitable established patriarchal connection between anatomy and desire, and between sexual activities and ascriptions of identity.

These characters believe, and hence attempt to revise or resignify received and established notions of masculine hegemony, with regard to their own desires and identities. By doing so, Woolf devalues the restraints of pleasures, roles and desires in the Lacanian symbolic order. Woolf's characters refuse to accept fixed sexual and gendered identity categories, and thus develop a kind of defiant desire under the ever-present influence of maternal power beyond the regular restraints of heteronormativity. Desire, which determines both the construction of identity and the type of language the characters use, is not reducible to the sole demands of sex or sexuality. Desire occupies the centre of Lacan's thought, and is a central concern of psychoanalysis. Dylan Evans notes that Lacan's concept of desire is mostly limited to "unconscious desires" which are not entirely sexual, and that "there is a limit to how far desire can be articulated in speech because of a fundamental 'incompatibility between desire and speech"' (Evans, 1996: 37); for this reason, I argue that desire cannot be fully articulated through symbolic language - meaning that another type of language is required for the articulation of desire.

The concept of desire in this study extends beyond sexual urges. Although desire holds its relation to its fundamental 'lack', it also acquires non-sexual connotations; the fundamental desire of a human being is interwoven with his/her fundamental lack, which is the maternal space from which he/she suffers abjection. When the maternal power exerts its influence upon the symbolic order, it causes the awakening of repressed desire for a maternal space that the characters once enjoyed. This space is what Kristeva calls the semiotic chora; it is "the place of the maternal law before the Law" (Oliver, 1993: 46). Kristeva describes the chora in this way:

The chora is a womb or a nurse in which elements are without identity and without reason. The chora is a place of a chaos which is and which becomes, preliminary to the constitution of the first measurable body...the chora plays with the body of the mother — of woman, but in the signifying process. (qtd. in Oliver, 1993: 46)

Kristeva often uses the term chora together with semiotic. As McAfee notes,

the chora is the space in which the meaning that is produced is semiotic: the echolalis, glossolalias, rhythms, and intonations of an infant who does not yet know how to use language to refer to objects, or of psychotic who has lost the ability to use language in a properly meaningful way. The semiotic chora may also make itself in symbolic communication (McAfee, 2004: 19).

Characters develop these desires under the influence of the maternal power in their conscious act of resistance against the limitations of the patriarchal values inscribed in the symbolic order. The characters do not stick to societies' rules and regulations, with regard to their own sexualities and identities; rather, they stick to their desire of the maternal space as the core fact of their lives, and as the constituent element of their identities. They revolt against the patriarchal symbolic order, since it separates them from their genuine and real semiotic desires, which offers them a distorted version of their desires, and ushers them towards a 'compulsory' heterosexuality.

The Name of the Father, which in Lacanian terminology is "the fundamental signifier which permits signification to proceed normally" (Evans, 1996: 122) and generally refers to the prohibitive role of the Father, nurtures "glorious monosexuality," and accordingly, fetters the free flow of desire for the original state of unity and wholeness. It prescribes heterosexuality as the only natural orientation of desire. The aforementioned 'compulsory' heterosexualityor entrapped monosexuality, which represses the unfettered nature of semiotic desires in the semiotic chora before entering into the patriarchal order of the symbolic - is mutually exclusive for both men and women. The un-Oedipalised, undifferentiated and disoriented desire of the maternal space in the semiotic is what characters are seeking to return to once more when they are located in the symbolic order.

\section{Jacques Lacan: The Birth of Desire}

The present study attempts to relate subjectivity to desire, informed by Virginia Woolf's radical revision on the notion of the construction of gender identity.

The real in Lacanian psychoanalysis does not refer to what commonly taken as reality, but rather the intractable world that resists and exceeds interpretation, articulation, and representation. It is "that which resists symbolization absolutely" (Lacan, 1988: The Seminar I. 66). It cannot be imagined, symbolised or known directly, because it lies beyond language. For this very reason, "there is no absence in the real" (Lacan, 1988: The Seminar II. 313). And 
because there is no lack, there is no language in the real: Lacan notes that language is always about loss or absence. Hence the real is always beyond, and cannot be represented in language; it is therefore irretrievably lost when one enters into language. Consequently, Lacan links "the real with the concept of impossibility" (Evans, 1996: 163). The real is, in short, "the impossible" (Lacan, 1964: The Seminar XI. 167).

Lacan's imaginary order is another of the three orders which constitute the tripartite scheme at the centre of Lacanian psychoanalysis. According to Evans the imaginary order is involved with "the formation of the ego in the mirror stage" (Evans, 1996: 84). Prior to the mirror stage, the infant experiences itself fragmentarily, and fragmented. This is the imaginary (also pre-Oedipal or pre-linguistic) stage, in which there is no clear recognition between the subject and the object. The infant cannot distinguish between the self and other: he/she is convinced that he/she is part of his/her mother, and confuses others with his/her own mirror reflections. Because the infant's knowledge of itself is based on such misrecognitions, he/she experiences a tremendously divided self (Evans, 1996: 118). But this stage is shattered through his recognition of individuality and alienation in the mirror stage, when for the first time the child can recognise the other. In this stage, the child experiences his separation from everything and everybody. And although the child cannot control his body, he is able to distinguish between his own image or body in the mirror, and the outside world. With his own recognition in the mirror, the child begins to undergo the introductory processes of identification, in which the child creates a kind of illusory experience of control of the self and the other. What the child anticipates is a sense of self as a unified separate whole; the child sees that it looks like what 'others' look like. Eventually this entity the child sees in the mirror, this whole being will be a 'self', the entity designated by the word 'I' (ibid.).

But in order to achieve full subjectivity, the child needs to enter the symbolic order, which is associated with the acquisition of language. It is language which dictates, determines and at the same time constructs positions for the subject, which clearly distinguishes exact boundaries between the self and others. After experimenting with the mirror stage, the child is compelled to enter the symbolic world of language by Oedipal conflict, for which Lacan uses the phrases The Name of the Father, and The No of the Father. As Evans notes "[t]he symbolic is the realm of the Law which regulates desire in the Oedipus complex. It is the realm of the culture as opposed to the imaginary order of nature" (Evans, 1996: 204). These phrases imply that how the father's emergence between the child and the mother forces the child to recognise alienation and separation, and to use language to differentiate between itself and others. Then the child experiences a system of linguistic differences, and therefore accepts language's predetermined position in such binary oppositions as male/female, father/son and so on. Consequently, linguistic expressions transform the child from a unity of being to split social being.

Lacan's symbolic order, which is loosely associated to Freud's reality principle, is the realm of law, language, society, and cultural beliefs. Entrance into this symbolic order determines one's subjectivity, in accordance to a primary law of referentiality wherein the male sign (phallus) is considered its ordering principle. Lacan states that both sexes submit to the "law of the phallus" (the law of order, language, and differentiation), but their individual relation to this law determines whether they see themselves as - and are seen by others to be - either masculine or feminine.

Therefore, the fundamental condition of human existence, according to Lacan, is "a relation of being to lack" (Grosz, 1990: 82). And it is through lack that desire arises:

Desire comes into existence through experiences of absence or lack (of the breast or the mother initially), not as the result of satisfaction. There is then something intrinsically painful and insatiable about desire itself. Any later experience of satisfaction always contains that first loss within it (Harding, 2001: 109).

According to Grosz, desire to Lacan is

an ontological lack which ensures the separation of the subject from the immediacy of its natural and social environment, and the impulse of that subject to fill in this space through, in the first instance, the desire of the (m)other; and in the second, through its access to language and systems of meaning (Grosz, 1989: xvi).

However, desire cannot be fully articulated in speech because of a fundamental "incompatibility between desire and speech" (Evans, 1996: 275); that is why the unconscious is by nature irreducible to full speech. Whenever speech insists on embodying desire, there is always a leftover, a surplus, which exceeds speech.

Lacan's subject thus only comes into being as the subject of language, in the sense of being subjected to language; the subject thereupon becomes split, finding the direction of its desire only in language and yet separated from it even farther by the original, and now repressed, quest for unity (Bertens and Natoli, 2002: 214). In this way, the desiring subject emerges out of the linguistic structures of the symbolic order. But what is the object of this desire? Key objects such as the mother's breast, the mother's voice, or the child's own faeces and urinary flow, which was previously experienced as part of the infant's own self, turn out to be recognised as being separate from the self. Lacan calls these key objects 'Object a,' which begin to function as the subject's primordial lack (rooted in the pre-Oedipal stage) in the symbolic order. As a result, the subject is always striving for a wholeness which is, in fact, an unquenchable desire for object a. This renders the subject split, and the object lost.

This absence at the heart of human existence places the subject within an ongoing dynamic of impossible longings. All apparent objects of desire in the life of the subject are thus merely metaphorical stand-ins for the true object of desirethe always lost and irreducibly anterior object $a$. Thus the subject is consigned to a "perpetual metonymic movement" from one object of desire to another, in search of a satisfaction that can never come (Booker, 1996: 37). 
For feminists, the different interpretations of phallus can lead to different conclusions: it might have a totally phallocentric underpinning, or an entirely feminist lead. It helps, however, to note that in reading Lacan, every concept has a linguistic bearing. For instance, the phallus, the protagonist in Lacan's narrative of the birth of desire, is a signifier:

No one has it, neither women nor men. It signifies the unnameable object of desire, the desire of the other, and it re-presents (stands in the place of) the objet a, the lost object in the real. And yet it can be said that this signifier is chosen because it stands out as what can be seized in the real of the sexual act. (Belsey, 1994: 63)

According to this interpretation of phallus, Lacan's account of desire is gender-neutral. The cause of desire is the lost object in the real, and the phallus is the privileged signifier of desire. Similarly, the father is also a signifier,

and it is the Name of the Father which authorises meaning, the paternal-signifying law which holds in place the ordering mechanisms of the symbolic. The Mother, too, is crucially a signifier, not a person, [but] 'the signifier of the primordial object' (Belsey, 1994: 59).

Thus, the underlying cause of desire in Lacanian psychoanalysis is the 'mother' and not the 'father'; and in this way, Lacanian psychoanalysis can be taken to be sympathetic to certain feminists.

\section{Towards Kristeva's Semiotic through écriture féminine: the Language of Resistance}

Lacan and his emphasis on the centrality of the masculine dominance over the symbolic made feminists especially Julia Kristeva revise Lacan's wholly inadequate account of the feminine and gender. She sees in the subject an opportunity for subversion of the masculine dominance. In Kristeva's usage of the term, the semiotic is a repertoire of the subject's drives and a decentered libidinal organisation. Although the semiotic may be expressed verbally, it does not follow the strict syntactic rules of the symbolic mode of signification, i.e. poetical and musical expressions. But the two modes are not completely separate: the semiotic can breach the boundaries of the symbolic in privileged moments of social transgression, and subvert its rules and operations. But if it has no specific syntactic rules, how then is the semiotic articulated in language, or remain part of the signifying process? Kristeva herself argues that the semiotic is "definitely heterogeneous to meaning" (qtd. in McAfee, 2004: 24).

In spite of the fact that the symbolic and the semiotic tend to be quite distinct orders, they are tightly related ones. Grosz argues that:

The semiotic and the symbolic are the two energies or movements enabling the subject to signify, to produce and use sign systems, discourses and to engage in social practices, as well as in their potential subversion. These terms refer to two distinct but related orders - that of signification (the symbolic) and that of subject formation (the semiotic). (Grosz, 1989: 42)

Following Kristeva's footsteps, one can trace the origin of the subject's desires in the semiotic. As Grosz states:

The semiotic involves both the inscription of polymorphous impulses across the child's body; and the return of these infantile inscriptions in adult form (her [Kristeva's] analogy is with Freud's concept of the symptom as the return of the repressed).They 'return' in the form of rhythms, intonations, melody accompanying all representation. They form a site, a threshold from which the earliest vocalizations, and eventually naming and language, can develop (Grosz, 1989: 44)

As Kelly Oliver points out, Kristeva claims to be concerned with discourses in which identity is broken down, such as the discourse of maternity, which is a discourse that "more than any other points to a subject-in-process" (Oliver, 1993: 48-9).

According to Kristeva, males and females develop different relations to language because of the separation from the mother at the mirror stage. Thus, the entry into the order of language and subjectivity for male and female children takes different shapes. The boy's relation to the mother and to language eases revolutionary writing, but the girl's relation to the mother and language suspends it (Kristeva, 1986: 1). This is because of the fact that boys go through a relatively easy Oedipal transition: they desire the mother's body, but are threatened with castration, and for this very reason leave the mother's body behind in hope of finding a mother-substitute of their own, and identifying with the father as a result. Girls, on the other hand, are already 'castrated,' and so there can be no castration threat to encourage them to give up the mother's body. Furthermore, it is harder for the girl to identify with the father. It is therefore "comfortable," Kristeva writes, for the girl to never give up the maternal body, the semiotic pre-linguistic stage, in which case she may either identify with her mother and become heterosexual, or continue to desire her mother and become lesbian (Kristeva, 1986: 37). In either case, because the girl never quite gives up the maternal, Kristeva argues that she will "remain in an eternal sulk before history, politics, society," existing in a "smug polymorphism" which is "so easy and comfortable for a woman" (Kristeva, 1986: 38). The "speech" of such women can make itself heard only through bodily manifestations, gestures, cries, hysterical symptoms (ibid.).

Kristeva makes it clear that if the woman writer allows herself to look back to the semiotic, she may never return, for the position of even a paternally-identified or "phallic" woman within patriarchy may not be enough to incite her to struggle to return to the symbolic. And the maternal body, unmitigated by the symbolic, threatens dissolution, delirium, chaos (Oliver, 1993: 12). As Chloë Taylor notes:

Women, then, according to Kristeva, have most often either over-identified with and desired the mother and lived silently incarnate existences, or have over-identified with and desired the father and become militants, 
devotees, or even fanatics of the structuring systems of society, whether these be religion, ethics, or politicsincluding fascism and feminism - because their sanity and lives have depended upon it. Men, however, can play between the paternal and maternal realms without undue risk, take up nuanced, ambivalent stances, because they are secure within the symbolic, and their play rarely really destabilises them. Holding a passport to the symbolic, to use Kelly Oliver's metaphor, men may more cavalierly transgress its rules, while women, as aliens, tread more warily. (Taylor, 2006: 59)

Kristeva believes that all change for women, whether political or literary, must take place from within the symbolic, since there is no articulation or language outside this realm.

I would like to show in this paper that there is a shared understanding of gender and maternity in Kristeva and Woolf, and that reading Woolf with Kristeva sheds light on the complexities of her novels. Woolf's characters explore the possibilities and often dangers of women making a bridge between the symbolic and the semiotic.

\section{Woolf and écriture féminine}

Early in the 20th century, Woolf epitomised the aspirations that several decades later would be more fully articulated by écriture féminine. Her juxtaposition of interrelated issues of language, the presence of the mother, and identity align her with the French feminists' views. The main point which French feminists and Woolf share is the exploration of the construction of a subject position in language, and how language is highly responsible for that particular construction. To connect écriture féminine to Kristeva's views discussed above, it is enough to note that the former aims to return to the semiotic chora through writing; and this return "encourages an obsession with the pre-Oedipal mother that can have disastrous consequences as it requires that a woman shed her single subject identity while simultaneously exposing herself to the full force of the unconscious drives" (Holden, 2006: 6). Throughout her texts, Woolf demonstrates the dangers of attempting to return to the lost mother, to the pre-Oedipal period. As Laura Holden notes:

Armed with connections between subjectivity, gender, and language that had been introduced by Lacan, l'écriture féminine began a movement to pursue the pre-symbolic mother who was repressed by the child at the time of separation from her body. This celebration of the return to the mother involved the rejection of the symbolic constructs of language and identity for the meaning that existed prior to those concepts, the meaning of the semiotic. This realm, where signified is without signifier, is a place of intense sensation that cannot be represented through language. The mother is the entrance into this world, and the pursuit of unity with her body is an attempt to find the elusive female language. (Holden, 2006: 26)

For instance, Cixous' ultimate goal was to subvert phallocentric language by shaking the strong and rigid boundaries between self and other. She does so by multiplying the experiences of the self, by attempting to expand signification in language. This for her functions metaphorically as an expansion of the self: through écriture féminine, signification can be released from the restraints of the singularity of meaning. She contours emancipation beyond the restriction of the signifier to one meaning.

[B]lurring the singularity of meaning into plurality and multiplicity can circumvent the oppressive logocentrism of language that is founded on the overvalued presence/absence of the phallus. This plurality, which is the woman's sex, will enable her to speak as well as to experience the jouissance of her body (Holden, 2006: 22).

In this mode of feminine writing, women attempt to return to the pre-symbolic period, which is tremendously repressed as the unconscious at the time of separation from the mother, and consequently making feminine language the language of the unconscious. Both Kristeva's and Cixous' practice of écriture féminine moves away from those known conventional linear discourses, in favour of a more fluid and multifaceted discourse. Kristeva's semiotic, in particular, disrupts the conventional linear discourse, valorises poetic language inspired by the maternal space, and aims at restoring the sensual, i.e., the auditory, visual, olfactory, and tactile.

According to Elaine Showalter, écriture féminine is "a practice of writing 'in the feminine' which undermines the linguistic, syntactical, and metaphysical conventions of Western narrative" (Showalter, 1986: 9). And going by this definition, one can observe Woolf's écriture féminine as the undermining of the sentence and the sequence of narrative, not only as a theory that she proposes in A Room of One's Own, but also as an essential part of her writing practice in Mrs. Dalloway, To the Lighthouse and The Waves. Woolf's technical experiments, such as the stream-of-consciousness narrative and the dislocation of grammatical structures, subvert the linguistic, syntactic, and metaphysical conventions of language and narrative. Woolf's understanding of how the feminine disrupts the symbolic structures of language, meaning, and writing anticipates the very similar views of Cixous and Kristeva. Kristeva notes that language is

a plurality of signifying systems of which each is one layer of a vast whole...Thus, gesturality, the various visual signals, and even the image, photography, cinema, and painting are so many languages to the extent that they transmit a message between a subject and an addressee by using a specific code, even though they do not obey the rules for the construction of verbal language that have been codified by grammar (Kristeva, 1989: 296)

This stress on plurality is a significant part of both Cixous' and Kristeva's account of écriture féminine, which gives way to the possibility of self-expression. In "The Laugh of the Medusa" (1980), Cixous urges that a woman writer 
must write herself, because this is the invention of a new insurgent writing which... will allow her to carry out the indispensable ruptures and transformations... By writing herself, women will return to the body which has been more than confiscated from her...censor the body and you censor breath and speech at the same time of language and meaning. (Cixous, 1980: 250)

We can perceive how Cixous' ruptures and transformations become an indispensable part of écriture féminine when they are reiterated by Kristeva as the process of "introducing ruptures, blank spaces, and holes into language" in order to dismantle symbolic systems (Kristeva, 1980: 165).

Woolf's creation of a shared poetic language between her characters in her novels introduces a kind of 'in-between writing'. The "multiplicity of meaning" which Woolf creates for her characters, according to Christina Kay Moriconi, moves them "beyond the categories of sexual difference" and their forms of streams-of-consciousness "highlight the androgynous mind." This is Woolf's conception of in-between writing, which "disrupt[s] the fixed structures of language" (Moriconi, 1996: 8).

One of the aims of écriture féminine is to move beyond the fixed confines of sexual difference, in order to introduce new forms and new writing practices. When the semiotic resurfaces in the symbolic, it introduces new possibilities beyond the fixed oppositions between men and women, such as the merging of them as in bisexual category. To achieve this, Kristeva emphasises a continuous interaction between symbolic establishment and semiotic rupture, while Cixous advocates women writing "through their bodies":

[T]hey must invent the impregnable language that will wreck partitions, classes, and rhetorics, regulations and codes; they must submerge, cut through, get beyond the ultimate reserve-discourse, including the one that laughs at the very idea of pronouncing the word 'silence'. (Cixous, 1980: 256)

\section{The Construction of In-between Gender Identity (Third Gender)}

Taylor describes the mechanism of the relationship between the symbolic and the semiotic in this way:

According to Kristeva the mother is abject, radically other, and both fascinates and disgusts, and must be symbolically murdered for the Subject - whether male or female, but the stakes are especially high for female Subjects - to enter into the symbolic, to avoid insanity and death, and to participate in time, history, and identity - to live. It is equally true, however, that we must retain the revolutionary potential of the maternal, or the semiotic, in order to bring change to the static and patriarchal order of the symbolic, to transform this into a society in which we would wish to live, making the paternal and the maternal necessary for politics (Taylor, 2006: 75)

Kristeva in fact encourages women to reject both identification with the mother or the father through the conscious act of resistance. Over-investing in neither the semiotic nor the symbolic, Kristeva suggests that women should secure a space in between. They should identify with the father just enough to gain their entry into the signifying system, language, culture, time, and history, but they should refuse to adopt fixed roles within this realm. Taylor summarises Kristeva's views in this respect and notes that:

[T]hey[women] should play with identities and never forget the semiotic music which they have (partially) left behind. In such a way, women can introduce the repressed, the maternal, the incomprehensible into language by maintaining an 'impossible dialectic' between the semiotic and the symbolic, constantly alternating between time and its 'truth,' identity and its loss, history and the timeless, signless, extraphenomenal things that produce it. (Taylor, 2006: 59-60)

Examples of these revolutionary acts can be found in Woolf's characters like Clarissa, Septimus, Lily, Rhoda and Bernard, who attempt this balanced position between two orders, never settling safely in either, who use the forms of the paternal — of order, time, and language - in order to inscribe the maternal, the timeless, the formless, and incomprehensible. Kristeva presumes Freud's view of fundamental bisexuality in all desiring subjects, a belief that assumes men also remain in a repressed relation to the feminine and the semiotic. As Grosz notes:

The burial of women under the phallocentric reduction to maternity is crippling for both mother and daughter. For the mother, it implies the constriction of her possibilities of self-definition and autonomy, her subjection to the Law of the Father, her subsumption under the name of her husband, and her giving up her identity as a woman (Grosz, 1990: 181).

\section{Conclusion}

Virginia Woolf refuses the 'either/or' logic of dichotomous models by offering a space which includes the advantages of both the symbolic and the semiotic, which in turn introduces the new logic of 'both/and'. This space fuses masculine and feminine identities. It is speech and pleasure, textuality and sexuality, sameness and difference. It is a space for both men and women; but arguably and preferably, it is a space the feminine may occupy without being silenced by masculinity, simply because it escapes the old binary opposition between masculinity and femininity."Third Gender" of characters could also be described as a deconstruction of personalities and their possibilities. Manning (2013) examines a range of literary works, from Shakespear to Woolf, to assert that "character is as much about dissolution of personality as about its construction, about the infinitely varied unacted parts as well as those which pass across the stage" (50). 
Considering “Third Gender” as possible "dissolution of personality” (Manning, 2013) and identity can open a space for new configurations and arrangements for identity politics.

\section{References}

Belsey, C. (1994). Desire: Love Stories in Western Culture. Oxford: Blackwell. Print.

Bertens, H. and Joseph, N. (2002) eds. Postmodernism: The Key Figures. Oxford: Blackwell Print.

Booker, K. M. (1996). A Practical Introduction to Literary Theory and Criticism. New York: Longman Print.

Cixous, H. (1980.) “The Laugh of the Medusa.” New French Feminisms: An Anthology. Eds. Elaine M and Isabelle de C New York: Schocken Print.

Derrida, J. (1991). "“Eating Well” or the Calculation of the Subject: An interview with Jacques Derrida' in Cadava et al., Who Comes After the Subject? New York: Routledge 96-119.

Evans, D. (1996). An Introductory Dictionary of Lacanian Psychoanalysis. New York: Routledge, Print.

Green, K. and Jill, L. (1996). Critical Theory and Practice: A Coursebook. London: Routledge.

Grosz, E. (1989). Sexual Subversion. Brisbane: Allen \& Unwi Print.

Grosz, E. (1990). Jacques Lacan: A Feminist Introduction. London: Routledge Print.

Hanson, C. (1994). Women Writers: Virginia Woolf. New York: St. Martin's, Print.

Harding, C. (2001). ed. Sexuality: Psychoanalytic Perspectives. East Sussex: Brunner-Routledge, Print.

Hargreaves, T. (2005). Androgyny in Modern Literature. Palgrave Macmillan, New York.

Helt, B. S. (2008). The Work of Bisexuality in Modernist Women's Writing: Sexual Epistemology, Modernist Aesthetics, Feminist Politics. Diss. University of Minnesot, Print.

Hilton, M. L. (1996). 'Splinters and Mosaics': Virginia Woolf and the Subjectivity of the Woman Artist. Diss. Acadia University, Print.

Holden, L. (2006). Virginia Woolf and the Pursuit of Female Language. Diss. California State University, Print.

Jantzen, G. M. (1999). Becoming Divine: Toward a Feminist Philosophy of Religion. Bloomington: Indiana University Press, Print.

Kristeva, J. (1980). "Oscillation between Power and Denial.” New French Feminisms: An Anthology. Eds. Elaine M and Isabelle de C. New York: Schocken, Print.

Kristeva, J. (1986). About Chinese Women. Trans. Anita Barrows. New York: Marion Boyars, Print.

Kristeva, J. (1989). Language the Unknown: An Initiation into Linguistics. Trans. Anne M. Menke. New York: Columbia University Press, Print.

Lacan, J. (1988). The Seminar. Book I. Freud's Papers on Technique, 1953-54, trans, with notes by John F, New York: Norton; Cambridge: Cambridge University Press.

Lacan, J. (1988). The Seminar. Book II. The Ego in Freud's Theory and in the Technique of Psychoanalysis, 1954-55, trans. Sylvana T notes by John F, New York: Norton; Cambridge: Cambridge University Press.

Lacan, J. (1964). The Seminar. Book XI. The Four Fundamental Concepts of Psychoanalysis, trans. Alan S (1977)

London: Hogarth Press and Institute of Psycho-Analysis.

Manning,S. (2013). "Did Human Character Change? Representing Women and Fiction from Shakespeare to Virginia

Woolf”. Project Muse. The Johns Hopkins University Press. 29-52.

Mansfield, N. (2000). Subjectivity: Theories of the Self from Freud to Haraway. Australia: Allen \& Unwin Print.

McAfee, N. (2004). Julia Kristeva. New York: Routledge, Print.

Moriconi, C. K. (1996). Writing Woman's Sentence: Virginia Woolf's L'écriture féminine. Diss. San Jose State University, Print.

Nyman, M. M. (2005). "Positioning Orlando as Subject in Lacan's Imaginary.” Virginia Woolf Miscellany 67: 19-21. Print.

Oliver, K. (1993). Reading Kristeva, Unraveling the Double-bind. Bloomington and Indianapolis: Indiana UP, Print.

Otsuka, R. (2008). Subject in Process: Modernist Characterization in Virginia Woolf's Mrs. Dalloway and To the Lighthouse. Diss. California State University, Print.

Parsons, D. (2007). Theorists of the modernist novel: James Joyce, Dorothy Richardson, and Virginia Woolf. New York: Routledge.

Showalter, E. (1986) ed. The New Feminist Criticism: Essays on Women, Literature and Society. London: Print. Taylor, C. (2006). "Kristevan Themes in Virginia Woolf's The Waves.” Journal of Modern Literature 29.3 : $57-77$. Print.

Woolf, V. (1929). A Room of One’s Own. New York: Harcourt Brace, Print.

---. To the Lighthouse. London: Wordsworth, 1994. Print.

---. Mrs. Dalloway. London: Wordsworth, 1996. Print.

---. The Waves. London: Wordsworth, 2000. Print. 